\title{
Transfer of the Bacteriochlorophyll $b$-Containing Phototrophic Bacteria Rhodopseudomonas viridis and Rhodopseudomonas sulfoviridis to the Genus Blastochloris gen. nov.
}

\author{
AKIRA HIRAISHI* \\ Department of Ecological Engineering, Toyohashi University of Technology, Toyohashi 441, and \\ Laboratory of Environmental Biotechnology, Konishi Co., Tokyo 130, Japan
}

\begin{abstract}
The phylogenetic positions of the bacteriochlorophyll (BChl) $b$-producing budding phototrophic bacteria Rhodopseudomonas viridis and Rhodopseudomonas sulfoviridis were studied on the basis of 16S rRNA gene sequence information. These bacteria formed a tight cluster with the genus Rhodoplanes as a sister group within the alpha-2 subgroup of the Proteobacteria. Genomic DNA-DNA hybridization assays showed that $R$. viridis and $\boldsymbol{R}$. sulfoviridis were closely related but were different species. Creation of the genus Blastochloris gen. nov. is proposed to accommodate these $\mathrm{BChl} b$-producing species of phototrophic bacteria.
\end{abstract}

In 1984 some species of the classically defined genus Rhodopseudomonas were reclassified into new genera, including the new genera Rhodobacter and Rhodopila, on the basis of modern taxonomic criteria (17). In recent years, the taxonomy of the genus Rhodopseudomonas has been further reevaluated on the basis of increasing molecular and chemotaxonomic information, and this has led to rejection of the name Rhodopseudomonas rutila (10) and the transfer of some Rhodopseudomonas species to the genus Rhodobacter (19) and to the new genera Rhodoplanes (12) and Rhodobium (13). Despite these taxonomic changes, the species currently in the genus Rhodopseudomonas are still heterogeneous phylogenetically, and both molecular and phenotypic data strongly suggest that only the type species, Rhodopseudomonas palustris, should be placed in this genus. The proper taxonomic placement of the bacteriochlorophyll (BChl) b-containing Rhodopseudomonas species (i.e., Rhodopseudomonas viridis and Rhodopseudomonas sulfoviridis) is a subject for consideration in light of their characteristic features. It has been suggested that one of the $\mathrm{BChl} b$-producing species, Rhodopseudomonas viridis, is phylogenetically distant from Rhodopseudomonas palustris (30) within the alpha-2 subgroup of the Proteobacteria and that this organism is more closely related to members of the genus Rhodoplanes (12). In the present study the $16 \mathrm{~S}$ ribosomal DNA (rDNA) sequence similarity of and genomic DNA relatedness between Rhodopseudomonas viridis and Rhodopseudomonas sulfoviridis were investigated. The results obtained indicate that these species should be placed in a distinct new genus of phototrophic bacteria, for which the name Blastochloris gen. nov. is proposed.

The organisms investigated were Rhodopseudomonas viridis ATCC $19567^{\mathrm{T}}(\mathrm{T}=$ type strain $)$, Rhodopseudomonas sulfoviridis DSM $729^{\mathrm{T}}$, Rhodoplanes roseus DSM $5909^{\mathrm{T}}$, and Rhodopseudomonas palustris ATCC $17001^{\mathrm{T}}$, all of which were obtained either from the American Type Culture Collection, Rockville, Md., or from the DSM-Deutsche Sammlung von Mikroorganismen und Zellkulturen $\mathrm{GmbH}$, Braunschweig, Germany. MYS medium (9), which contained mineral base RM2, $20 \mathrm{mM}$ sodium DL-malate as the carbon source, and $0.05 \%$ yeast extract as the growth factor, was used for cultiva-

${ }^{*}$ Mailing address: Department of Ecological Engineering, Toyohashi University of Technology, Tenpaku-cho, Toyohashi 441, Japan, Phone: 81 (532) 44-6913. Fax: 81 (532) 44-6547. tion of the organisms. For Rhodopseudomonas sulfoviridis, the medium was supplemented with $10 \mathrm{mM}$ glucose, $2 \mathrm{mM}$ sodium sulfide (neutralized), and $2 \mathrm{mM}$ thiosulfate. The medium was supplemented with $10 \mathrm{mM}$ pyruvate (filter sterilized) for Rhodoplanes roseus. The organisms were grown at $30^{\circ} \mathrm{C}$ in screwcap test tubes under anaerobic conditions in the light. Cells were harvested by centrifugation from cultures at the midexponential phase of growth, washed, resuspended in pure water or EDTA-saline, and stored at $-20^{\circ} \mathrm{C}$ until analysis. Genomic DNA was extracted and purified by the method of Marmur (24). DNA base ratios were determined by the highperformance liquid chromatography method $(7,18)$, and DNA-DNA hybridization assays were performed by photobiotin labeling and colorimetric detection as described previously $(7,10)$. 16S rDNA fragments were amplified by PCR from the crude cell lysate (11) and were purified by polyethylene glycol precipitation $(8,22)$. The PCR products were sequenced directly with fluorescent primers and a SequiTherm Long-Read cycle sequencing kit (Epicentre Technologies, Madison, Wis.) and analyzed with a Pharmacia automated DNA sequencer. Sequences were compiled and similarities were calculated with the GENETYX-MAC computer program (Software Development Co., Tokyo, Japan). Multiple alignments of sequences, calculation of nucleotide substitution rates (21), and construction of neighbor-joining phylogenetic trees (27) were performed with the CLUSTAL W program (28). Alignment positions that included gaps and unidentified bases were not taken into consideration for the calculations.

The 16S rDNA sequences determined covered a continuous nucleotide stretch from positions 28 to 1,492 in the Escherichia coli numbering system (1). The level of sequence similarity between the 16S rDNAs of Rhodopseudomonas viridis and Rhodopseudomonas sulfoviridis was $98.7 \%$ (corrected distance, 0.0123 ). This binary similarity value suggests that the two species are phylogenetically closely related organisms which belong to a single genus but different genospecies. The results of DNA-DNA hybridization assays supported this suggestion, as the genomic DNAs of Rhodopseudomonas viridis and Rhodopseudomonas sulfoviridis were related to each other at an average hybridization level of $38 \%$ (Table 1). A distance matrix tree was constructed on the basis of the 16S rDNA sequences of Rhodopseudomonas viridis, Rhodopseudomonas sulfoviridis, and related species of phototrophic and nonphototrophic bacteria that belong to group 2 of the alpha subclass of the Proteobacteria (Fig. 1). The two species of $\mathrm{BChl} b$-producing pho- 
TABLE 1. Genomic DNA relatedness among Rhodopseudomonas viridis, Rhodopseudomonas sulfoviridis, and some other species of budding phototrophic bacteria

\begin{tabular}{|c|c|c|c|}
\hline \multirow[t]{2}{*}{ Organism } & \multirow{2}{*}{$\begin{array}{c}\mathrm{G}+\mathrm{C} \text { content } \\
\text { of DNA } \\
(\mathrm{mol} \%)\end{array}$} & \multicolumn{2}{|c|}{$\begin{array}{c}\text { \% Hybridiza- } \\
\text { tion with la- } \\
\text { beled DNA } \\
\text { from: }\end{array}$} \\
\hline & & $\begin{array}{l}\text { ATCC } \\
19567^{T}\end{array}$ & $\begin{array}{l}\text { DSM } \\
729^{T}\end{array}$ \\
\hline Rhodopseudomonas viridis ATCC $19567^{\mathrm{T}}$ & $66.5^{a}$ & 100 & 32 \\
\hline Rhodopseudomonas sulfoviridis DSM $729^{\mathrm{T}}$ & 67.9 & 44 & 100 \\
\hline Rhodoplanes roseus DSM $5909^{\mathrm{T}}$ & $66.8^{b}$ & 11 & 7 \\
\hline Rhodopseudomonas palustris ATCC $17001^{\mathrm{T}}$ & $65.0^{a}$ & 6 & 4 \\
\hline
\end{tabular}

${ }^{a}$ Data from reference 10.
${ }^{b}$ Data from reference 12.

totrophs formed a tight cluster with the genus Rhodoplanes as a sister group within the alpha- 2 subgroup of the Proteobacteria.

BChl $b$ was first discovered in Rhodopseudomonas virids (3, 5) and was later found in some other species of phototrophic purple bacteria, including members of the genera Thiocapsa (4) and Ectothiorhodospira $(15,16)$. Among the species of the genus Rhodopseudomonas and all other genera of purple nonsulfur bacteria so far recognized, however, Rhodopseudomonas viridis and Rhodopseudomonas sulfoviridis are the only species that produce $\mathrm{BChl} b$ as the photosynthetic pigment. In addition to these species, a $\mathrm{BChl} b$-producing budding phototrophic bacterium which may be related to the former species has been isolated from a hot spring (26). The evolutionary and taxonomic significance of the presence of $\mathrm{BChl} b$ is not clear. However, 16S rDNA sequence comparisons demonstrate that the $\mathrm{BChl} b$-producing budding phototrophic bacteria studied here form a monophyletic group that is distinguishable from Rhodopseudomonas palustris, other members of the genus Rhodopseudomonas, and all other photosynthetic genera established so far in the alpha-2 subgroup. Phylogenetic analysis

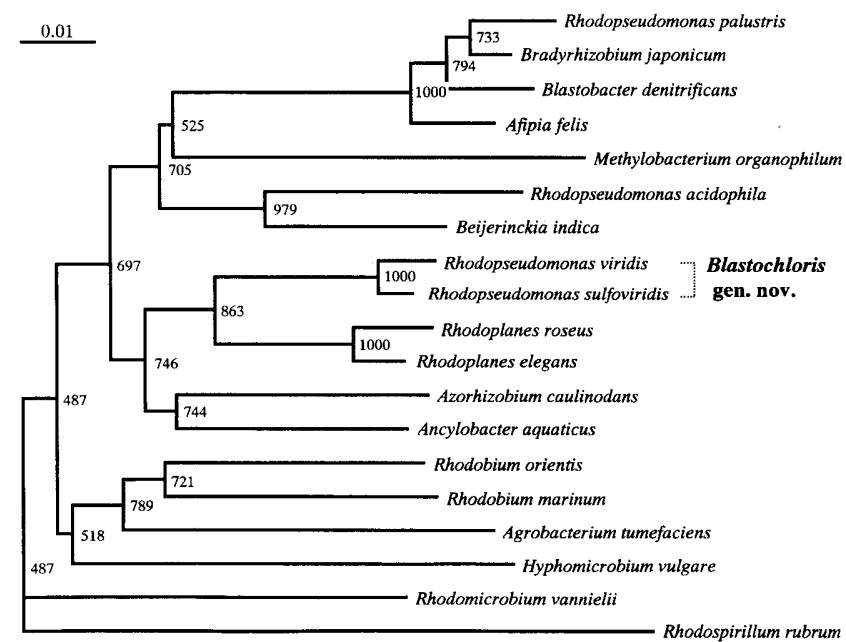

FIG. 1. Distance matrix tree showing phylogenetic affiliations of Rhodopseudomonas viridis, Rhodopseudomonas sulfoviridis, and related species of phototrophic and nonphototrophic bacteria belonging to the alpha- 2 subgroup of the Proteobacteria. The 16S rDNA sequence of Rhodospirillum rubrum was used as an outgroup to root the tree. Bootstrap confidence values obtained from 1,000 bootstrap trials (6) are given at branch points. Scale bar $=1$ nucleotide substitution per 100 nucleotides. based on amino acid sequences of $\mathrm{L}$ and $\mathrm{M}$ subunit proteins of photosynthetic reaction centers showed that Rhodopseudomonas viridis represents a unique line of descent within the division of purple bacteria (25). Rhodopseudomonas viridis is one of the best characterized organisms with respect to structures of the reaction center, as X-ray crystal structures of the reaction center of this organism have been studied (2). In light of the importance of Rhodopseudomonas viridis as a key organism in photosynthetic research and the phylogenetic and phenotypic evidence that the $\mathrm{BChl} b$-producing budding phototrophs are members of a distinct taxonomic group, these organisms should no longer be included in the genus Rhodopseudomonas. Thus, I propose that Rhodopseudomonas viridis and Rhodopseudomonas sulfoviridis should be transferred to the genus Blastochloris gen. nov., as Blastochloris viridis comb. nov. and Blastochloris sulfoviridis comb. nov., respectively.

Description of Blastochloris gen. nov. Blastochloris (Blas.to. chlo'ris. Gr. n. blastos, bud shoot; Gr. adj. chloros, green; M. L. fem. n. Blastochloris, green bud shoot). The characteristics described below are based on information from previous reports $(3,14,20,23,29)$ and this study. Cells are rod shaped to ovoid and exhibit polar growth, budding, and asymmetric cell division. Rosette-like aggregates sometimes occur. Motile by means of subpolar flagella. Gram negative. Photoheterotrophic, growing anaerobically in the presence of light. Microaerophilic growth in the dark is also possible. Phototrophically growing cells contain intracytoplasmic membranes that are present as lamellae underlying and parallel to the cytoplasmic membrane. Photosynthetic pigments are $\mathrm{BChl} b$ and carotenoids. The color of photosynthetic cultures is green to olive green. Photoorganotrophy with a number of simple organic compounds as carbon and electron donors is the preferred mode of growth. Both ubiquinones (Q-8 to Q-10) and menaquinones (MK-7 to MK-9) are present. The $\mathrm{G}+\mathrm{C}$ content of the genomic DNA ranges from 66 to $71 \mathrm{~mol} \%$. 16S rDNA sequence information places the genus in the alpha-2 subgroup of the Proteobacteria, and the genus Rhodoplanes is the closest relative among the photosynthetic genera. The type species is Blastochloris viridis.

Description of Blastochloris viridis comb. nov. Blastochloris viridis (Rhodopseudomonas viridis Drews and Giesbrecht 1966, $261^{\mathrm{AL}}$ ) (vi'ri.dis. L. adj. viridis, green). The description of $B$. viridis is the same as the description given previously for Rhodopseudomonas viridis $(3,23,29)$. The type strain is strain ATCC 19567 (= DSM 133 = G. Drews F).

Description of Blastochloris sulfoviridis comb. nov. Blastochloris sulfoviridis (Rhodopseudomonas sulfoviridis Keppen and Gorlenko 1975, 258 ${ }^{\mathrm{AL}}$ ) (sul.fo.vi'ri.dis. L. neut. n. sulphur, sulfur; L. adj. viridis, green; L. adj. sulfoviridis, sulfur green). The description of $B$. sulfoviridis is the same as the description given previously for Rhodopseudomonas sulfoviridis $(20,29)$. The type strain is strain DSM $729\left(=\mathrm{V}\right.$. M. Gorlenko $\left.\mathrm{P}_{1}\right)$.

Nucleotide sequence accession numbers. The nucleotide sequences of the 16S rDNAs of Rhodopseudomonas viridis and Rhodopseudomonas sulfoviridis have been deposited in the DDBJ, EMBL, and GenBank databases under accession numbers D25314 and D86514, respectively.

\section{REFERENCES}

1. Brosius, J., J. L. Palmer, J. P. Kennedy, and H. F. Noller. 1978. Complete nucleotide sequence of a $16 \mathrm{~S}$ ribosomal RNA gene from Escherichia coli. Proc. Natl. Acad. Sci. USA 75:4801-4805.

2. Deisenhofer, J., O. Epp, R. Miki, R. Huber, and H. Michel. 1985. Structure of the protein subunits in the photosynthetic reaction centre of Rhodopseudomonas viridis at $3 \AA$ resolution. Nature 318:618-624.

3. Drews, G., and P. Giesbrecht. 1966. Rhodopseudomonas viridis, nov. spec., ein neu isoliertes, obligat phototrophes Bakterium. Arch. Mikrobiol. 53: $255-262$. 
4. Eimhjellen, K. E. 1970. Thiocapsa pfennigii sp. nov., a new species of phototrophic sulfur bacteria. Arch. Mikrobiol. 73:193-194.

5. Eimhjellen, K. E., O. Aasmundrud, and A. Jensen. 1963. A new bacterial chlorophyll. Biochem. Biophys. Res. Commun. 10:232-236.

6. Felsenstein, J. 1985. Confidence limits on phylogenies: an approach using the bootstrap. Evolution 39:783-791.

7. Hiraishi, A., Y. Hoshino, and T. Satoh. 1991. Rhodoferax fermentans gen nov., sp. nov., a phototrophic purple nonsulfur bacterium previously referred to as the "Rhodocyclus gelatinosus-like" group. Arch. Microbiol. 155: 330-336.

8. Hiraishi, A., Y. Kamagata, and K. Nakamura. 1995. Polymerase chain reaction amplification and restriction fragment length polymorphism analysis of 16S rRNA genes from methanogens. J. Fement. Bioeng. 79:523-529.

9. Hiraishi, A., and H. Kitamura. 1984. Distribution of phototrophic purple nonsulfur bacteria in activated sludge systems and other aquatic environments. Bull. Jpn. Soc. Sci. Fish. 50:1929-1937.

10. Hiraishi, A., T. S. Santos, J. Sugiyama, and K. Komagata. 1992. Rhodopseudomonas rutila is a later subjective synonym of Rhodopseudomonas palustris. Int. J. Syst. Bacteriol. 42:186-188.

11. Hiraishi, A., Y. K. Shin, Y. Ueda, and J. Sugiyama. 1994. Automated sequencing of PCR-amplified 16S rDNA on "Hydrolink" gels. J. Microbiol. Methods 19:145-154.

12. Hiraishi, A., and Y. Ueda. 1994. Rhodoplanes gen. nov., a new genus of phototrophic bacteria including Rhodopseudomonas rosea as Rhodoplanes roseus comb. nov. and Rhodoplanes elegans sp. nov. Int. J. Syst. Bacteriol. 44:665-673.

13. Hiraishi, A., K. Urata, and T. Satoh. 1995. A new genus of marine budding phototrophic bacteria, Rhodobium orientis gen. nov., sp. nov. and Rhodobium marinum comb. nov. Int. J. Syst. Bacteriol. 45:226-234.

14. Imhoff, J. F. 1984. Quinones of phototrophic purple bacteria. FEMS Microbiol. Lett. 25:85-89.

15. Imhoff, J. F., and Trüper. 1977. Ectothiorhodospira halochrolis sp. nov., a new extremely halophilic phototrophic bacterium containing bacteriochlorophyll $b$. Arch. Microbiol. 114:115-121.

16. Imhoff, J. F., and Trüper. 1977. Ectothiorhodospira abdelmalekii sp. nov., a new halophilic and alkaliphilic phototrophic bacterium. Zentralbl. Bakteriol. Parasitenkd. Infektionskr. Hyg. Abt. 1 Orig. Reihe C, 2:228-234.

17. Imhoff, J. F., H. G. Trüper, and N. Pfennig. 1984. Rearrangements of the species and genera of the phototrophic "purple nonsulfur bacteria." Int. J. Syst. Bacteriol. 34:340-343.

18. Katayama-Fujimura, Y., Y. Komatsu, H. Kuraishi, and T. Kaneko 1984.
Estimation of DNA base composition by high performance liquid chromatography of its nuclease P1 hydrolysate. Agric. Biol. Chem. 48:3169-3172.

19. Kawasaki, H., Y. Hoshino, A. Hirata, and K. Yamasato. 1993. Is intracytoplasmic membrane structure a generic criterion? It does not coincide with phylogenetic interrelationships among phototrophic purple nonsulfur bacteria. Arch. Microbiol. 160:358-362.

20. Keppen, O. I., and V. M. Gorlenko. 1975. A new species of purple budding bacteria containing bacteriochlorophyll $b$. Mikrobiologiya 44:258-264.

21. Kimura, M. 1980 . A simple method for estimating evolutionary rates of base substitution through comparative studies of nucleotide sequences. J. Mol. Evol. 16:111-120.

22. Kusukawa, N., T. Uemori, K. Asada, and I. Kato. 1990. Rapid and reliable protocol for direct sequencing of material amplified by the polymerase chain reaction. BioTechniques 9:66-72.

23. Lang, F. S., and D. Oesterhelt. 1989. Microaerophilic growth and induction of the photosynthetic reaction center in Rhodopseudomonas viridis. J. Bacteriol. 171:2827-2834.

24. Marmur, J. 1961. A procedure for the isolation of deoxyribonucleic acid from micro-organisms. J. Mol. Biol. 3:208-218.

25. Nagashima, K. V. P., S. Hanada, A. Hiraishi, K. Shimada, and K. Matsuura. 1995. Phylogenetic analysis of photosynthetic reaction centers of purple bacteria and green filamentous bacteria, p. 975-978. In P. Mathis (ed.), Photosynthesis: from light to biosphere, vol. 1. Kluwer Academic Publishers, Dordrecht, The Netherlands.

26. Resnick, S. M., and M. T. Madigan. 1989. Isolation and characterization of a mildly thermophilic nonsulfur purple bacterium containing bacteriochlorophyll $b$. FEMS Microbiol. Lett. 65:165-170.

27. Saitou, N., and M. Nei. 1987. The neighbor-joining method: a new method for reconstructing phylogenetic trees. Mol. Biol. Evol. 4:406-425.

28. Thompson, J. D., D. G. Higgins, and T. J. Gibson. 1994. CLUSTAL W: improving the sensitivity of progressive multiple sequence alignment through sequence weighting, position-specific gap penalties and weight matrix choice. Nucleic Acids Res. 22:4673-4680.

29. Trüper, H. G., and J. F. Imhoff. 1989. Genus Rhodopseudomonas Kluyver and van Niel in Czurda and Maresch 1937, $119^{\mathrm{AL}}$, p. 1672-1677. In J. T. Staley, M. P. Bryant, N. Pfennig, and J. G. Holt (ed.), Bergey's manual of systematic bacteriology, vol. 3. The Williams \& Wilkins Co., Baltimore, Md.

30. Woese, C. R., E. Stackebrandt, W. G. Weisburg, B. J. Paster, M. T. Madigan, V. J. Fowler, C. M. Hahn, P. Blanz, R. Gupta, K. H. Nealson, and G. E Fox. 1984. The phylogeny of purple bacteria: the alpha subdivision. Syst. Appl. Microbiol. 5:315-326. 